\title{
PEMIKIRAN PENDIDIKAN PROGRESIF IVAN ILICH DALAM PERSPEKTIF FILSAFAT PENDIDIKAN ISLAM DI ERA MILLENIAL
}

\author{
Sofa Muthohar \\ UIN Walisongo, Semarang, Indonesia \\ sofamuthohar@walisongo.ac.id
}

Fatah Syukur

UIN Walisongo, Semarang, Indonesia

fsyukur@walisongo.ac.id

\section{Mahfud Junaedi}

UIN Walisongo, Semarang, Indonesia

mahfud_junaedi79@yahoo.com

DOI: 10.20885/tarbawi.vol13.iss1.art1

\begin{abstract}
This study discusses Ivan Illich's progressive ideas from the perspective of Islamic Education Philosophy in the millennial era. This study uses a qualitative library research approach and uses content analysis. The results of this study indicate that there are several principles of learning from Ivan Illich that are in line with Islamic Education Philosophy. Firstly, the meaning of learning as knowledge sharing activities is not a school commodity. Secondly, there is equality of learning rights and without discrimination. While the principles that are considered unsuitable include two things. Firstly, the goal of Islamic education is to make people of good morals (akhlaqul karimah), while the learning objective of Ivan Illich is to realize social equality. Secondly, according to Ivan Illich, the concept of a perfect human being is human with full of hope based on effort and negates mercy (epimetheus), whereas, in Islam, a perfect person is a person of noble character (ulul albab). As for the context of the millennial generation, Ivan Illich's progressive education will be very
\end{abstract}


useful in supporting an active, creative, dynamic, and confident attitude that will be balanced if it is complemented by the spiritual nature of religiously based education.

Keywords: Progressive Education, Ivan Illich, Islamic Education Philosophy, and Millennial Era

\section{Abstrak}

Kajian ini membahas tentang gagasan progresif Ivan Illich dari perspektif Filsafat Pendidikan Islam di era milenial. Penelitian ini menggunakan pendekatan penelitian pustaka kualitatif dan menggunakan analisis isi. Hasil penelitian ini menunjukkan bahwa terdapat beberapa prinsip pembelajaran Ivan Illich yang sejalan dengan Filsafat Pendidikan Islam. Pertama, pengertian pembelajaran sebagai kegiatan knowledge sharing bukanlah komoditas sekolah. Kedua, ada persamaan hak belajar dan tanpa diskriminasi. Sedangkan prinsip yang dianggap tidak sesuai mencakup dua hal. Pertama, tujuan pendidikan Islam adalah mewujudkan akhlak masyarakat yang baik (akhlakul karimah), sedangkan tujuan pembelajaran Ivan Illich adalah mewujudkan kesetaraan sosial. Kedua, menurut Ivan Illich, konsep manusia sempurna adalah penuh harapan berdasarkan usaha dan meniadakan belas kasihan (epimetheus), sedangkan dalam Islam, orang sempurna adalah orang yang berakhlak mulia (ulul albab). Sedangkan untuk konteks generasi milenial, pendidikan progresif Ivan Illich akan sangat bermanfaat dalam menunjang sikap aktif, kreatif, dinamis dan percaya diri yang akan diimbangi jika diimbangi dengan pendidikan yang bersifat spiritual dan berbasis agama.

Kata Kunci: Pendidikan Progresif; Ivan Illich; Filsafat Pendidikan Islam; Era Milenial. 


\section{Pendahuluan}

Persoalan pendidikan terus berkembang sangat dinamis seiring dengan perkembangan peradaban manusia khsusnya pada generasi millennial. Peran pendidikan dianggap sangat penting seiring dengan perkembangan ilmu pengetahuan yang sangat pesat khususnya pada masyarakat industri 4.0. Ilmu bukan hanya perperan sebagai wawasan, namun lebih dari itu, ilmu telah menjadi komoditas.Semua anak wajib untuk menempuh pendidikan, itu adalah wajib belajar. Ada kewajiban belajar enam tahun ada pula negara yang kemudian mewajibkan wajib belajar 9 sembilan tahun seperti di Indonesia. Sekolah telah dianggap sebagai jembatan untuk menjadi orang yang baik, orang yang terdidik dan orang yang mampu bekerja. Orang yang tidak lulus dalam pendidikan dasar akan dianggap sebagai aib dan beban bagi negara. Itulah kenapa pemerintah selalu berpacu untuk meningkatkan Angka Partisipasi Anak (APA) dalam pendidikan dasar yang dikenal dengan istilah Angka Partisipasi Murni (APM) dan Angka Partisipasi Kasar (APK). Angka ini menjadi salah satu simbol kesuksesan bagi kepemimpinan daerahnya di bidang pemerataan pendidikan.

Sekolah sebagaimana awalnya yang dimaksud oleh orang Yunani dengan kata schole yaitu waktu luang untuk mengembangkan wawasan (Illich, $2002 \mathrm{hlm}$. 138) dalam aktifitasnya sekarang ini tidak lagi sebagai kegiatan di waktu luang, namun justru sebagai waktu inti dalam kegiatan sehari-hari. Anak-anak dalam jangka waktu yang sangat lama menghabiskan hampir seluruh waktunya untuk kegiatan sekolah. Bahkan orientasinya hidupnya dipertaruhkan untuk bisa sukses di sekolah. Di sisi lain anak-anak yang gagal dan tidak lulus sekolah, apalagi sekolah dasar dicap oleh masyarakat sebagai anakanak yang gagal dalam hidupnya. 
Dalam koteks kuatnya peran kelembagaan sekolah ini, pemikiran Ivan Illich ditempatkan. Beliau memandang sekolah telah melampaui peran-perannya sebagai salah satu media mendidik manusia, bahkan sekolah telah merampas kebebasan anak untuk memilih cara belajarnya sendiri.

\section{Metode Penelitian}

Karena mempelajari pemikiran seseorang yang terdokumentasi dalam karya-karya tulisnya, penelitian ini merupakan jenis penelitian pustaka. Seperti dinyatakan oleh Supriyadi (2016) bahwa dalam penelitian pustaka, peneliti berhadapan langsung dengan data tekstual, maka dalam hal ini penulis berhubungan langsung dengan karya-karya Ivan Illich maupun sumber-sumber tekstual yang membahas pemikiran Ivan Illich. Pendekatan yang digunakan adalah pendekatan kualitatif dengan melakukan konten analisis.

\section{Hasil Penelitian Dan Pembahasan}

\section{Biografi Ivan Illich}

Seorang yang sangat dinamis, Ivan Illich, lahir di Wina tahun 1926. Menempuh pendidikan Teologi di Universitas Gregoria, Roma dan meraih gelar doktor dalam ilmu sejarah di Universitas Salzburg, yang kemudian di angkat menjadi imam Gereja Katolik Roma.

Pada tahun 1951, ia pergi ke New York Amerika Serikat dan banyak berkarya di tengah imigran Irlandia di Puerto Rico. Selanjutnya, pada tahun 1956-1976, Illich banyak melakukan penelitian dan seminar tentang Instituonal Alternative in a Technolgical Society dengan fokus studi tentang Amerika Latin. 
Gayanya yang menentang arus dan komitmennya terhadap "humanisme radikal" telah membawanya sebagai seorang "hero" bagi kaum Katolik Kiri sebagaimana di Indonesia seperti Romo Mangun. Gaya yang demikian menjadikannya banyak tidak dimengerti oleh hierarki gereja dan lembaga-lembaga konvensional.

Karya-karya Ivan Illich yang berupa essai banyak tersebar di The New York Review, The Saturday Review, Esprit, Kursbuch, Siempre, America, Commenwealth, Espreuves dan Temps Modern. Sedangkan buku-bukunya antara lain: Deschooling Society atau yang diterjemahkan menjadi "Bebaskan Masyarakat dari Belenggu Sekolah" telah mendapat penghargaan dari World Board of Education; Medical Namesis telah diterjemahkan menjadi "Batas-batas Pengobatan" tahun 1995, Celebration of Awarenes; Tool for Convivality; Energy and Equity; dan Shadow Work; Vernacular Gender telah diterjemahkan menjadi "Matinya Gender"(Illich, 2000, hlm. 164-165).

\section{Pemikiran Pendidikan Progresif Ivan Illich}

Awal mula ketertarikan Illich untuk memikirkan dunia pendidikan dimulai dari perjumpaannya dengan Everett Reimer di Puerto Rico (negara bagian Amerika Serikat) pada tahun 1958. Ketika itu, muncul kesadaran bagi kebanyakan orang, bahwa hak untuk belajar telah dibatasi oleh kewajiban bersekolah (Illich, 2000: hlm.ix). Oleh karena itu, persoalan dominasi sekolah dalam kehidupan masyarakat telah menjadi perhatian utama Ivan Illich.

Berdasar pada karya monumentalnya "Deschooling Society" yang merupakan kumpulan catatan Illich selama aktif di Center for Intercultural Documentation (CIDOC) dapat diambil inti gagasan pendidikannya diantaranya adalah:

Pertama, melucuti kemapanan sekolah. Institusi sekolah sudah menjadi lembaga yang seakan-akan identik dengan pendidikan. 
Realitas pemikiran masyarakat sudah terbangun bahwa sekolah adalah satu-satunya lembaga pendidkan (Illich, 2000, hlm.3). Sekolah secara komprehensif masa kini, bersifat wajib, memakan waktu sepanjang tahun, dan harus hadir di kelas selama beberapa jam sehari (Illich, 2002 hlm. 127). Sistem sekolah semacam ini, telah membangun sebuah jembatan sempit sebagai satu-satunya jalan untuk menyeberangi jurang sosial yang semakin dalam. Sebagai satusatunya lintasan yang sah menuju kelas menengah, membatasi lintasan lain yang non-konvensional dan membiarkan orang yang gagal untuk menanggungnya sendiri (Illich, 2001 hlm.519).

Kurikulum tersembunyi selalu menjadi ciri dari sekolah di manapun. Kurikulum yang menuntut semua anak pada umur tertentu harus berkumpul dalam satu kelas yang berjumlah kurang lebih 30 anak, di bawah bimbingan guru berijazah dan menghabiskan waktu 500 sampai 1000 jam pertahun (Illich, 2001 hlm. 519). Tidak perduli apakah di dalamnya mengajarkan tentang fasisme, sosialisme, liberalisme, katolikisme. Tidak peduli apakah di dalamnya mengajarkan tentang menjadi warga negara yang baik di Amerika atau pun tempat lain, tidak peduli apakah gurunya otoriter atau liberal. Namun yang jelas bahwa kurikulum tersembunyi telah mengubah "belajar tentang dunia" lebih bernilai dari "belajar dari dunia", mengubah "belajar" dari sebuah kegiatan menjadi komoditas di mana sekolah memonopoli pasar (Illich, 2001 hlm. 519).

Berbagai dampak muncul sebagai akibat dari dominasi paradigma sistem sekolah ini, di antaranya: (a). Monopoli isu. Seakanakan menjadi suatu kesalahan jika ada anak umur sekolah namun tidak masuk sekolah. Baik orang kaya maupun orang miskin samasama mengalami ketergantungan ini sehingga berakibat pada kesimpulan apa yang sah dan apa yang tidak sah, baik dalam masalah pendidikan maupun kesehatan. Akibat dari ketergantungan ini, mereka menganggap bahwa mengobati diri sendiri ataupun belajar 
mandiri adalah tindakan yang tidak bertanggung jawab dan bisa dianggap subversi. Bahkan mereka menjadi sangat sangsi akan kemampuan diri sendiri dalam menyelesaikan masalah (Illich, 2000 hlm.3). Semua diserahkan pada ahlinya dan berbiaya, pendidikan diserahkan ke sekolah dan kesehatan diserahkan pada rumah sakit. Mereka sendiri tidak mempunyai kekuasaan dan kepercayaan terhadap kemampuanya sendiri, sampai pada persoalan-persoalan kecil. (b). Kuatnya dominasi sekolah terhadap pola interaksi masyarakat. Ini berakibat pada ukuran kemiskinan yang digunakan oleh pemerintah. Yang dimaksud orang miskin di Meksiko adalah mereka yang tidak menempuh pendidikan sekolah dasar tiga tahun, sedangkan disebut miskin di New York adalah mereka yang berpendidikan di bawah dua belas tahun. (c). Kuatnya ketergantungan. Penanganan kemiskinan terutama di Amerika Serikat dengan mendapatkan pelayanan pendidikan dasar dan kesehatan, telah mengubah pola pikir dan menjadikan ketergantungan mereka dalam menyelesaikan persoalan hidupnya. Parahnya ketergantungan mereka terhadap pelayanan, selalu diikuti biaya yang harus ditanggung baik oleh dirinya maupun oleh anggaran negara (Illich, 2000 hlm.2-5). Posisi ini justru lebih menegaskan kelemahan orangorang miskin. Mental menunggu pelayanan dan bukannya kemandirian telah berbuntut pada biaya hidup yang sangat mahal. Kaum miskin di Amerika dipaksa untuk mengembalikan anaknya ke sekolah dan dibiayai, atau seorang dokter menyediakan kamar dirumah sakit dengan biaya 60 dolar perhari bagi warganya yang tidak mampu (Illich, 2000 hlm.5). (d). Kontraproduktifitas. Dampak terparah adalah munculnya kontraproduktifitas (contraproductivity) dalam dunia pendidikan. Yaitu suatu istilah yang digunakan sebagai lambang frustasi yang dirasakan kelompok atau kelas tertentu sebagai akibat dari adanya kewajiban konsumsi barang atau jasa. Dalam dunia Pendidikan, hal ini bisa berupa hilangnya makna belajar yang 
diakibatkan dari ketumpulan kurikulum itu sendiri (Illich, 1997, hlm. 143). Atas nama sistem pendidikan, masyarakat di wajibkan sekolah. Mereka yang tidak ikut dianggap gagal. Namun, di sisi lain, ketika masyarakat sudah mengikuti tingkatan demi tingkatan, tingkat kebutuhan terhadap pendidikan terus meningkat sampai pada suatu kebutuhan yang tidak mungkin terpenuhi dalam dunia pendidikan itu sendiri. Dalam istilah Ivan dikatakan bahwa "sekolah adalah persiapan utama untuk membuat manusia terperangkap dalam perangkapnya sendiri" (Illich, 2000 hlm. 147).

Kedua, Adanya "ritualisasi kemajuan". Ritual Gereja telah menciptakan sistem permintaan pelayanan bahkan sampai urusan orang meninggal dunia. Adanya konsep api suci yang dapat mensucikan jiwa yang sudah mati, dan munculnya konsep perdagangan pengampunan dosa telah menggeser kepercayaan terhadap hidup abadi menjadi "mitos konsumsi tanpa henti" (Illich, 2000, hlm.58-59). Dengan mengutip pendapat Arnold Toynbee, Illich menunjukkan bahwa kemerosotan suatu kebudayaan besar biasanya disertai dengan munculnya "Gereja Sedunia" yang memberi harapan kepada kaum proletar setempat sambil melayani kelas kesatria baru. Nampaknya, sekolah kini sudah memiliki sifat-sifat Gereja Sedunia yang sekular, ilmiah dan mengingkari kematian, adanya mitos tentang nilai, pengukuran dan paket nilai sebagai komoditas. Di dalamnya terdapat kurikulum yang menggunakan garis ilmu pengetahuan, dan ilmu pengetahuan menggunakan garis penelitian ilmiah yang tidak ada batasnya. Sehingga tidak ada seorang pun yang pernah menyelesaikan sekolahnya, pendidikan berkelanjutan, terus menerus tanpa henti, sehingga sepanjang hidupnya dapat dihabiskan di sekolah (Illich, 2000 hlm.47-59).

Sekolah telah menjadi media yang efektif untuk mencipta mitos sosial dan melestarikannya, karena struktur permainan di dalamnya bertujuan untuk menaikkan jabatan sosial berjenjang. Masuk ke dalam 
ritus permainan ini dianggap lebih penting daripada apa yang diajarkan. Seluruh masyarakat dimasukkan dalam mitos konsumsi tanpa henti akan jasa pendidikan ini. Keikutsertaannya menjadi ritus tanpa akhir sebagai kewajiban. Kewajiban ini berlaku dimana saja di seluruh dunia internasional. Permainan ini mewajibkan para pesaingnya untuk menjadikan orang-orang yang tidak ikut bermain sebagai kambing hitam untuk dituduh sebagai sumber munculnya persoalan dunia (Illich, 2000 hlm. 59-60). Berkat (blessing) hanya diperuntukkan bagi mereka yang mampu menumpuk investasi waktu mereka selama bertahun-tahun di sekolah. Dengan hal ini sekolah bukan hanya menjadi agama baru dunia, namun telah berkembang menjadi pasar kerja yang paling pesat perkembangannya di dunia (Illich, 2000 hlm.62).

Ketiga, Spektrum Kelembagaan. Di bawah judul "Sekolah sebagai Sarana Umum yang Palsu," Illich menjelaskan tentang spektrum kelembagaan sekolah yang sangat manipulatif. Sebagaimana jalan tol (bebas hambatan), sekilas sekolah seakan-akan memberikan peluang kepada semua orang untuk masuk dan menggunakan fasilitas di dalamnya. Dalam kenyataannya sekolah hanya terbuka bagi mereka yang mampu membayar dan memperbaharui keanggotaannya, dengan alasan operasional dan mengikuti ilmu pengetahuan dan teknologi. Jalan bebas hambatan telah menjadi sarana umum yang palsu dengan menunjukkan ketergantungan kepada mobil pribadi, sebagaimana sekolah yang didasarkan pada hipotesis palsu bawa kegiatan belajar adalah hasil dari kegiatan pengajaran berdasarkan kurikulum yang direcanakan. Jalan bebas hambatan telah membelokkan keinginan dasar manusia untuk bergerak menjadi kebutuhan akan mobil pribadi, sedangkan sekolah membelokkan keinginan dasar manusia untuk belajar menjadi kebutuhan untuk masuk sekolah (Illich, 2000 hlm. 81). 
Dengan melepaskan tanggung jawab pribadi dalam belajar, sekolah telah mengambil alih kegiatan belajar atas nama kurikulum. Dalam spektrum yang lebih besar sekolah telah banyak menyebabkan orang-orang untuk bunuh diri secara spiritual. Upaya yang dilakukan untuk menggeser perbuatan mulia "belajar" menjadi produk pelayanan pendidikan. Menjadikan sekolah disamakan dengan pendidikan itu sendiri, dan menjadikannya sama dengan produkproduk layanan yang lain. Layanan pendidikan, lebih diinginkan daripada belajar itu sendiri, barang-barang sekali pakai lebih dinginkan daripada barang yang tahan lama dan bisa direparasi. Dalam bidang peneltian pendidikan, keadaan ini dituntut untuk bisa membalik keadaan (Illich, 2000 hlm. 85-86).

Keempat, Konsistensi Irasional. Konsistensi seorang guru yang menerapkan kurikulum dengan tujuan untuk mencapai tujuan pembelajaran ideal pada satu sisi telah membebani siswa. Suatu konsisitensi yang sedemikan menakutkan, namun sekaligus menantang dan menggugah kehidupan sehari-hari. Dua hal yang sebenarnya tidak bisa disatukan yaitu suatu hal yang sifatnya wajib tidak bisa menjadi kegiatan bebas dalam ekspresi. Konsistensi irasional ini menjadikan masyarakat menuntut pengelola sekolah untuk bertanggungjawab terhadap atas perubahan prilaku yang dialami aleh siswa-siswa mereka (Illich, 2000 hlm. 87-91).

Para pembaharu pendidikan menganggap sekolah berfungsi sebagai corong dari program yang mereka rencanakan. Sebenarnya bukan masalah program apa, atau siapa yang ada di dalamnya, namun yang lebih mendasar adalah bahwa sekolah tersebut diselenggarakan dan dikelola oleh pendidik sehingga relasinya menjadi antara si pemasok dan konsumen. Suatu revolusi dibutuhkan untuk membalik keadaan melui pembalikan ganda dari pembalikan orientasi penelitian untuk tidak lagi bias kultural dan orientasi pendidikan baru yang tadinya lebih melayani tujuan guru menjadi menjadi orientasi yang 
memungkinkan orang untuk dapat menentukan kegiatan belajarnnya sendiri sendiri dan bagaimana setiap orang dapat menyumbang bagi kegiatan belajar orang lain (Illich, 2000, hlm.93-94).

Kelima, Sekolah Pembebasan. Di sekolah, siswa tunduk pada guru yang berijazah untuk mendapatkan ijazah. Namun, berdasarkan laporan dari Komisi Cornegie bahwa baik guru maupun siswa menjadi frustasi dan menyalahkan kurangnya sumber-sumber daya, uang, waktu atau gedung sebagai biang keladi dari frustasi mereka. Anehnya, ketika orang-orang didesak untuk menjawab pertanyaan dari manakah mereka mendapatkan pengetahuan yang berharga bagi dirinya, mereka mengakui bahwa hal itu lebih banyak diperoleh di luar sekolah daripada di dalam sekolah. Pengetahuan mereka mengenai fakta, mengenai kehidupan dan cara kerja lebih banyak diperoleh dari persahabatan dan cinta, menonton TV, membaca, contoh dari teman sebaya atau dari tantangan yang mereka jumpai di jalan dan lain-lain. Hal tersebut mendorong untuk menemukan format kegiatan belajar yang lain.

Sesuatu yang bisa menjadi titik tolak adalah fenomena kurikulum terselubung di mana sekolah mengajarkan mitos mitos. Mitos bahwa birokrasi yang dijalankan secara ilmiah akan lebih baik dan efisien. Mitos bahwa produksi yang semakin meningkat akan melahirkan kehidupan yang lebih baik. Mitos kurikulum membawa pembelajaran pada penipuan diri sendiri untuk mengkonsumsi jasa dan ketergantungan terhadap lembaga dan sikap menerima peringkat yang dibuat oleh lembaga (Illich, 2000, hlm. 95-98) Pososi pendidikan China menjadi penting untuk belajar. China selama tiga ribu tahun telah melindungi pendidikan tinggi dengan cara memisahkan antara proses belajar dengan hak istimewa yang diberikan. Demi tekat untuk menjadi kekuatan dunia dan negara bangsa yang modern, China harus mengambil alih corak sekolah internasional. Peninjauan kembali dilakukan untuk mengetahui apakah Revolusi Kebudayaan Besar 
akan berhasil menghapuskan ketergantungan terhadap lembaga dan mengembalikan fungsi asalnya (Illich, 2000, hlm. 98-99).

Pendidikan baru yang membebaskan setidaknya mempunyai ciri-ciri umum antara lain: (a). sistem pendidikan bertujuan menyediakan kesempatan bagi semua orang yang ingin belajar untuk mengakses sumber-sumber belajar kapan pun mereka mau; memberikan kebebasan kepada orang yang ingin berbagi ilmu untuk menemui siapa saja orang yang ingin belajar dari mereka, dan memberikan kebebasan kepada semua orang untuk menyampaikan masalahnya agar diketahui umum. Para pelajar tidak boleh dipaksa untuk tunduk pada suatu kurikulum, dan tidak dipaksa untuk tunduk pada deskriminasi yang didasarkan apakah mereka punya sertifikat atau ijasah. (b). Lembaga pendidikan dirancang dengan asumsi bahwa ada suatu rahasia mengenai segala sesuatu, di mana kualitas hidup tergantung bagaimana seseorang dapat menyingkap rahasia itu. Kunci penyingkapan itu ada pada kemampuan guru bukan pada lembaga. Lembaga tidak berpretensi untuk membuat piramida-piramida paket keilmuan dan bebas di akses oleh siapapun yang ingin belajar tanpa terikat oleh surat izin dan tahapan-tahapan pembelajaran sebelumnya (Illich, 2000 hlm. 99-100). (c). Lembaga pendidikan mempunyai educational web. Yaitu jaringan atau media yang dapat digunakan untuk saling bertukar gagasan dan temuan secara bebas dari semua orang. Bukan network yang hanya digunakan untuk maksud maksud penguatan lembaga, namun sebaliknya. educational web sebagai media bertukar karya. Bukan seperti jaringan TV yang searah kepentingannya namun jaringan di mana semua orang bisa memberi warna. (Illich, 2000 hlm. 101-102) (d). Mempunyai sasaran pendidikan untuk membebaskan akses atas nilai-nilai pendidikan mereka dari kontrol orang atau lembaga, membebaskan usaha membagikan keterampilan atau mengajar sesuai permintaan, membebaskan sumber-sumber daya kritis masyarakat untuk mengumpulkan dan 
mengadakan pertemuan dan membebaskan individu dari kewajiban menggantungkan harapannya pada jasa-jasa baik yang diselenggarakan oleh profesi mapan ataupun tidak mapan (Illich, 2000 hlm. 137-138).

Keenam, konsep manusia sempurna. Pentingnya mengemukakan konsep manusia sempurna yang diidealkan adalah untuk mengetahui muara dari keseluruhan ide progresifitas Ivan Illich. Pada bagian akhir bukunya "Deschooling Society", Ivan Illich membahas tentang Manusia Ephimetheus (Illich, 2000, hlm. 140-155). Konsepsi manusia sempurna Ivan Illich ini nampak masih belum menemukan formatnya yang pasti, dia hanya mengusulkan nama dengan karakter manusia yang penuh harapan. Nama Ephimetheus diambil dari mitos dewadewa Yunani.

Kisah mitos yang menjadi kepercayaan orang-orang Yunani Kuno ini bermula dari kisah dua bersaudara Prometheus dan Epimetheus. Prometheus berpesan kepada saudaranya agar tidak berhubungan dengan Pandora. Namun Epimetheus malah mengawininya. Pandora yang makna aslinya sang pemurah, adalah seorang Dewi Bumi. Ia membawa kendi yang di dalamnya terdapat banyak penyakit dan juga terdapat harapan. Namun, pandora membiarkan kendi itu mengeluarkan semua penyakit dan menutupnya kembali sebelum harapannya keluar. Dalam budaya Yunani diabadikan dengan kotak mainan yang disebut kotak pandora.

Tersebarnya penyakit yang dibawa Pandora membuat Prometheus sibuk untuk mengatasinya. Usaha ini disebut dalam periode sejarah dengan pembentukan lembaga untuk mengatasi persoalan yang dihadapi masyarakat. Terbentuklah lembaga ciptaannya yang dapat mengatasi penyakit, sehingga manusia tergantung padanya dengan mengharapkan sistem lembaga berjalan dengan baik. Keadaan ini telah menjadikan tingginya hope (ketergantungan harapan berdasar kasih sayang) dan menurunya 
el-Tarbawj Sofa Muthohar, Fatah Syukur \& Mahfud Junaedi

ekspektasi (harapan berdasar usaha). Hope (harapan) adalah percaya akan kebaikan alam; sedangkan ekspektasi (harapan) adalah mengandalkan hasil yang telah direncanakan dan dikendalikan manusia. Harapan berpusat pada keinginan akan datangnya orang yang akan memberi hadiah. Sedangkan harapan, menanti hasil dari usaha manusia yang bisa diprediksi dan bisa dituntut (Illich, 2000, hlm. 140-141).

Seiring dengan perubahan masyarakat dari matrialkhal ke patrialkhal, Epimetheus menentang saudaranya dengan mengawini Pandora, sehingga Epimetheus berhasil mendapatkan harapan (expectation). Keadaan ini menggambarkan kembali harapan masyarakat untuk mengandalkan karya dan kemampuannya sendiri bukan mengharap kasih sayang. Manusia seperti ini digambarkan oleh Ivan Illich dengan bait - bait puisi:

Tidak ada orang yang tidak menarik

Nasib mereka bagaikan kisah planet-planet

Tidak ada satupun yang tidak membawa ciri khas dalam dirinya

Dan planet yang satu tidak sama dengan planet yang lainnya.

Dan jika manusia hidup dalam kekelaman,

Namun bisa menjalin persahabatan dengan para sahabatnya,

Kekelaman bukan lagi hal yang menjemukan(Illich, 2000 hlm. 154)

Demikian konsep manusia sempurna dalam perspektif Ivan illich yang secara singkat dapat digambarkan sebagai Epimetheus, manusia yang penuh harapan terhadap usaha yang dilakukannya. Mampu mencipta dan berkarya, mengandalkan kekuatan dirinya untuk meraih masa depannya. 


\section{Pemikiran Pendidikan Ivan Illich dalam Perspektif Filsafat Pendidikan Islam}

Ivan Illich telah melihat dominasi sekolah yang luar biasa sebegai pemegang otoritas dalam pendidikan dan pembelajaran. Sekolah yang awalnya merupakan kegiatan manusia untuk mengisi luang telah berubah menjadi suatu yang wajib diikuti oleh semua orang, baik warga negara dari Puerto Rico, New York dan hampir di semua negara di belahan dunia ini. Institusi sekolah telah memonopoli pendidikan dan pembelajaran.

Pergeseran peran dari mengisi waktu luang menjadi suatu yang wajib dalam perspektif Ivan Illich, telah membawa dampak besar dan sangat membahayakan. Orang akan dikatakan gagal dalam hidupnya hanya dilihat dari ketidakmampuanya untuk menyelesaikan pendidikan dasar, bahkan anak yang gagal sekolah akan dianggap sebagai beban negara dan menjadikan nilai negara di mata negara lain menjadi turun.

Peran sistem sekolah dalam posisi yang sangat dominan seperti ini secara langsung telah membunuh keberadaan pembelajaranpembejaran yang dilakukan orang di luar sistem sekolah. Menjadikan aktifitas pembelajaran sebagai komoditas.

Orang-orang yang melakukan pembelajaran mandiri, mereka dikatakan ilegal, tidak diakui, ataupun tidak dipandang oleh masyarakat sebagai suatu yang bermakna. Sebagaimana hadirnya dominasi medis di dunia kesehatan. Praktek pengobatan tradisional dikatakan melanggar dan tidak diberi ruang dalam kehidupan masyarakat dan dianggap sebagai suatu bentuk pelanggaran dalam menangani penyakit.

Fenomena sekolah yang menggeser aktifitas belajar menjadi komoditas yang diperjualbelikan bisa membawa kepada hal-hal yang kadang di luar nalar. Apa yang dikatakan Pierre Bourdieo sebagai 
kekerasan simbolik (Martono, 2012 hlm. 47-49) di mana secara tidak sadar kadang guru atau sekolah membuat aturan yang menguntungkan anak-anak yang mampu, melayani mereka yang punya fasilitas dan di sisi yang lain menomorduakan orang-orang miskin.

Dalam konteks Indonesia, dominasi ini juga terjadi. Menjadi suatu hal yang aneh bahkan bisa disebut sebuah kejahatan jika ada orang tua yang mempunyai anak di usia sekolah namun tidak dimasukkan ke sekolah. Dinas pendidikan setempat akan datang dan menanyakan apa sebabnya. Bahkan tidak segan-segan akan membujuk orang tuanya untuk memasukkan anaknya ke sekolah dan digratiskan. Hal ini dilakukan karena pemerintah menerapkan aturan untuk setiap tahunnya Angka Partisipasi Anak (APA) dalam pembelajaran harus meningkat. Bahkan hal ini secara global dalam Millenium Development Goals (MDGis) dijadikan sebagai salah satu indikator pembangunan Sumber Daya Manusia (SDM).

Dalam perspektif Filsafat Pendidikan Islam bisa dilihat dari beberapa sisi. Pertama, Mengembalikan makna belajar sebagai kegiatan berbagi ilmu bukan komoditas sekolah, Pemikiran Ivan Illich yang sangat menaruh perhatian terhadap pergeseran makna belajar dari awalnya merupakan suatu yang bebas dan merupakan hak dasar manusia, telah berubah menjadi komoditas (suatu yang diperjualbelikan), dari konsep "pembelajaran" menjadi konsep "sekolahan". Konsep tersebut merupakan pandangan yang juga pernah ada dalam sejarah filsafat pendidikan Islam. Al-Ghazali (1111 M) melarang mengambil honor dari mengajar agama. Secara sekilas jika pandangan Al-Ghazali dilihat dari cara pandang pengajaran agama zaman sekarang, pernyataan itu seakan menjadi aneh dan kehilangan konteksnya. Namun dengan logika Ivan Illich ini, pelarangan al Ghazali bisa dimengerti. Walaupun dapat dipastikan bahwa ke dua tokoh ini sangat berbeda dalam konteksnya. Al-Ghazali 
secara utuh didasarkan pada nash-nash al-Qur'an dan Hadits sedangkan Ivan Illich memahami dari sisi orang yang tidak beragama.

Kedua, Kesetaraan hak belajar tanpa diskriminasi. Dalam prinsip-prinsip Filsafat Pendidikan Islam dikenal adanya prinsip tawazun (setara, berimbang), di mana pendidikan Islam haruslah terhindar dari kesenjangan-kesenjangan, terhindar dari diskriminasi dan kontradiksi antar bagian dan juga tidak pula ekstrim ke salah satu arah (Langgulung, 2003, hlm. 43). Dilihat dari prinsip keseimbangan ini, pemikiran Ivam Illich berusaha untuk menyeimbangkan antara dominasi sekolah dengan budaya belajar. Sekolah yang telah memonopoli pembelajaran sebagai komoditi jangan sampai melupakan hakikat pembelajaran itu sendiri. Hakikat keingintahun itu sendiri yang akan berakibat pada kemampuan seseorang menjalani hidupnya. Ada kesamaan ide, namun ada juga perbedaan sudut pandangnya. Persamaannya adalah sama-sama tidak ingin adanya ketidakseimbangan dan tiadanya dominasi. Sedangkan perbedaannya ada pada tujuan akhir dari keseimbangan tersebut. Keseimbangan yang dimaksud Ivan Illich adalah keseimbangan praktek pendidikan dan tiadanya dominasi kelas dalam pembelajaran. Tidak memihak salah satu baik formal ataupun non-formal, semuanya diakui dan berakibat pada perlakuan yang sama. Sedangkan tujuan keseimbangan dalam konsep Filsafat Pendidikan Islam lebih luas dari sekedar perlakuan kelas, seimbang yang dimaksud dalam semua sisinya, seimbang dalam urusan dunia dan akhirat, seimbang jasmani dan rohani, seimbang antara yang material dan spiritual.

Ketiga, tujuan pendidikan adalah menghilangkan kelas sosial, bukan memperlebarnya. Konsep pendidikan Ivan Illich mempunyai tujuan utama persamaan kelas sosial dengan menghilangkan penindasan. Adanya dominasi sekolah yang mempunyai monopoli pendidikan, telah membuat jurang perbedaan kelas dan bersifat menindas kreatifitas. Sedangkan tujuan pendidikan Islam menurut 
Abdul Fatah Jalal dalam buknya Min Ushul al-Tarbawiyah fi al-Islam (Muhaimin, 2004, hlm. 48) menyatakan bahwa tujuan umum pendidikan Islam adalah untuk mewujudkan manusia sebagai hamba Allah berdasar al-Qur'an Surat at-Takwir ayat 27, atau bisa dilihat dari tujuan prilakunya berkembang secara maksimal sesuai dengan ajaran Islam (Tafsir, $1994 \mathrm{hlm}$. 32) atau berakhlaqul karimah dan memberikan rahmat bagi alam semesta dengan tidak memihak salah satu kelas. Dalam hal ini, konsep Ivan Illich mempunyai mempunyai perbedaan dengan tujuan pendidikan Islam. Tujuan pendidikan Islam untuk menjadikan orang berakhlak yang baik (akhlaqul karimah), sedangkan tujuan pembelajaran konsep Ivan Illich adalah untuk mewujudkan kesetaraan sosial.

Keempat, konsep manusia sempurna yang mengedepankan harapan berdasar usaha dan meniadakan belas kasihan. Konsep Ivan Illich di ambil dari mitos Yunani Kuno tentang cerita dewa-dewa yang penuh harapan. Dewa yang mewakili semangat penuh harapan di sebut dengan nama Epimetheus. Profil manusia yang otimis, kreatif, dinamis, mandiri penuh harapan dengan usahanya sendiri. Sedangkan konsep manusia sempurna menurut Pendidikan Islam bisa dikatakan Insan Kamil dengan ciri-ciri diantaranya (a). Jasmani yang sehat dan kuat (b). Cerdas serta pandai; (c). Rohani yang berkualitas tinggi penuh keimanan kepada Allah Swt. (Tafsir, 1994, hlm. 41-46). Keduanya mempunyai kesamaan akan manusia yang ideal yang penuh usaha, kreatif dan mandiri. Namun Terdapat satu kelemahan konsep pendidikan progresif Ivan Illich mengenai konsep manusia sempurna yaitu dalam konsep Islam tentang Insan Kamil adalah manusia yang mempunyai harapan, usaha dan doa harus seimbang, sedangkan dalam konsep ephimetheus manusia ideal adalah manusia yang penuh harapan berdasarkan usahanya sendiri (expectation) yang meniadakan ketergantungan (hope). 


\section{Pendidikan Era Millenial}

Istilah Millennial adalah istilah cohort (istilah kependudukan yang bermakna set/group dari orang yang memiliki kriteria yang sama) dalam demografi, yaitu kata millennial yang berarti pengikut atau kelompok. Saat ini ada empat cohort besar dalam demografi, yaitu Baby Boomer (lahir pada tahun 1946-1964), Gen-X (lahir pada tahun 19651980), Millennial (Y) (lahir pada tahun 1981-2000), dan Gen-Z (lahir pada tahun 2001-sekarang) (Al Walidah, 2018). Rouse mengungkapkan bahwa Millennials, dikenal dengan Generation $Y$ atau Net Generation. Sedangkan Neil Howe and William Strauss, pengarah buku Generations: The History of America's Future, 1584 to 2069, menyebut millennial cohort adalah mereka yang lahir antara tahun 1982 and 2004 (Rouse, t.t.).

Generasi millennial saat ini (pada tahun 2019) adalah mereka yang berusia 19-38 tahun; mereka yang kini berperan sebagai mahasiswa dan early jobber. Menurut data BPS yang dikeluarkan pada tahun 2013, jumlah millennial Indonesia tahun 2020 mencapai 34\% yang akan berada pada usia 20 hingga 40 tahun. Pada tahun tersebut, generasi millennial akan menjadi tulang punggung perekonomian Indonesia. Generasi dalam era millennial ini seperti: google generation, net generation, echo boomers, dan dumbest generation. Oleh karena itu, masyarakat generasi millennial itu bisa ditandai dengan meningkatnya penggunaan alat komunikasi, internet, Whatsapp, Youtube, Facebook dan lain lain (Al Walidah, 2018).

Abudin Nata, berpendapat bahwa terdapat 14 sikap dan perilaku sekaligus tantangan generasi milenial mempunyai ciri-cirinya antara lain: (1) suka dengan kebebasan; (2) senang melakukan personalisasi; (3) mengandalkan kecepatan informasi yang instant (siap saji); (4) suka belajar; (5) bekerja dengan lingkungan inovatif, (6) aktif berkolaborasi, dan (7) hyper technology (Tapscott, 2008) (8) critivcal, 
yakni terbiasa berfikir out of the box, kaya ide dan gagasan; (9) confidence, yakni mereka sangat percaya diri dan berani mengungkapkan pendapat tanpa ragu-ragu; (10) connected, yakni merupakan generasi yang pandai bersosialisasi, terutama dalam komunitas yang mereka ikuti; (11) berselancar di sosial media dan internet sebagai akibat dari ketergantungan yang tinggi terhadap internet dan media sosial, mereka menjadi pribadi yang malas, tidak mendalam, tidak membumi, atau tidak bersosialisasi; (13) cenderung lemah dalam nilai-nilai kebersamaan, kegotongroyongan, kehangatan lingkungan dan kepedulian sosial; (14) cenderung bebas, kebaratbaratan dan tidak memperhatikan etik dan aturan formal, adat istiadat, serta tata krama (Nata, 2018). Sementara itu, Hasanuddin Ali dan Lilik Purwandi sebagaimana dikutip oleh Iffah menyederhanakan ciri ciri generasi milenial menjadi tiga karakter utama, yaitu 3C: connected, creative, dan confidence (Al Walidah, 2018).

Dalam konteks era Millenial ini, pemikiran pendidikan progressif Ivan Illich mampu memberikan progresifitas anak didik agar mempunyai sifat yang aktif, kreatif dan dinamis yang seharusnya dilengkapi dengan pengendalian diri secara moral dengan pendidikan agama. Perpaduan dari pendidikan progresif dan pendidikan agama akan mempunyai keseimbangan pribadi generasi millennial agar mampu memenangkan persaingan dan hidup bahagia.

Dengan demikian pemikiran Ivan Illich dalam perspektif Filsafat Pendidikan Islam terdapat kesamaan di antaranya dari sisi makna pembelajaran dan konsep keseimbangan. Tedapat perbedaan jika dilihat dari sisi tujuan pendidikan dan konsep manusia sempurna.

\section{Kesimpulan}

Konsep pendidikan progresif Ivan Illich secara umum dapat disimpulkan terdapat lima pemikiran dasar: (a) melucuti kemapanan 
sekolah; (b) mengkritik ritualisasi kemajuan; (c) spektrum kelembagaan; (d) sekolah pembebasan dan (e) konsep manusia sempurna.

Ditinjau dari sisi Filsafat Pendidikan Islam terdapat hal-hal yang sesuai dan tidak sesuai. Kesesuaian antara keduanya dalam hal; pertama, mengembalikan makna belajar sebagai kegiatan berbagi ilmu bukan komoditas sekolah, kedua, kesetaraan hak belajar tanpa diskriminasi. Sedangkan perbedaannya pada konsep tujuan pembelajaran. Tujuan pendidikan Islam untuk menjadikan orang berakhlak yang baik (akhlakul karimah, sedangkan tujuan pembelajaran konsep Ivan Illich adalah untuk mewujudkan kesetaraan sosial. Selain itu, terdapat konsep manusia sempurna yang mengedepankan harapan berdasar usaha dan meniadakan belas kasihan (Epimetheus), sedangkan dalam Islam adalah orang yang berakhlak mulia (ulul albab). Sedangkan dalam konteks genrasi milenial, maka pendidikan progresif Ivan Illich akan sangat berguna dalam menunjang sifat aktif, kreatif, dinamis dan confidence yang akan berimbang jika di lengkapi dengan sifat spiritual pendidikan yang barbasis agama.

\section{Daftar Pustaka}

Al Walidah, I. (2018). Tabayyun di Era Generasi Millenial. Jurnal Living Hadis, 2(2), 317-344.

Illich, I. (1997). Gender. Terj. Matinya Gender. Pustaka Pelajar.

Illich, I. (2000). Deschooling Society, Terj. Bebaskan Masyarakat Dari Belenggu Sekolah (II). Yayasan Obor Indonesia.

Illich, I. (2001). Alternative Persekolahan, dalam Paulo Freire,dkk, Menggugat Pendidikan Fundamentalis, Konservative, Liberal, Anarkis. Pustaka Pelajar.

Illich, I. (2002). Celebration of Awareness: A Call for Instituonal Revolution. Terj. Perayaan Kesadaran: Agama, Pendidikan, Kesejahteraan Sosial. Ikon Tralitera. 
el-Tarbawj Sofa Muthohar, Fatah Syukur \& Mahfud Junaedi

Langgulung, H. (2003). Asas-Asas Pendidikan Islam. PT Pustaka alHusna Baru.

Martono, N. (2012). Kekerasan Simbolik di Sekolah, Sebuah Ide Sosiologi Pendidikan Pierre Bourdieu. PT. Raja Grafindo Persada.

Muhaimin, M. dkk. (2004). Paradigma Pendidikan Islam, Upaya Mengefektifkan Pendidikan Agama Islam di Sekolah. PT. Remaja Rosdakkarya.

Nata, A. (2018). Pendidikan Islam di Era Milenial. Conciencia, 18(1), 10-28.

Rouse, M. (t.t.). What is Millennials (Generation Y)? - Definition from WhatIs.com. WhatIs.Com. Diambil 9 Agustus 2019, dari https://whatis.techtarget.com/definition/millennials-millennialgeneration

Supriyadi. (2016). Community of Practitioners: Solusi Alternatif Berbagi Pengetahuan antar Pustakawan. Lentera Pustaka, 2 (2), 83-93.

Tafsir, A. (1994). Ilmu Pendidikan dalam Perspektif Islam (2 ed.). PT. Remaja Rosdakkarya. 